\title{
O IMPACTO DO ICMS VERDE NOS MUNICÍPIOS PRIORITÁRIOS DO ESTADO DO PARÁ ${ }^{1} / /$ Lise Tupiassu ${ }^{2}$, Jean-Raphaël Gros-Désormeaux ${ }^{3}$, Luiz Paulo de Sousa Leão Fadel ${ }^{4}$
}

\author{
Palavras-chave \\ tributação ambiental / ICMS Verde / municípios \\ prioritários / Estado do Pará
}

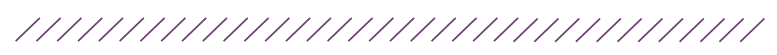

\section{Sumário}

1 Introdução

2 Fundamentos teóricos e base constitucional do ICMS Verde

3 O ICMS Verde no Estado do Pará

4 Os Municípios Prioritários e o ICMS Verde

5 Análise dos repasses financeiros aos Municípios Prioritários do Estado do Pará

6 Conclusão

7 Referências

\section{Resumo}

O ICMS Verde consiste no dimensionamento dos repasses financeiros decorrentes da repartição do produto da arrecadação do Imposto sobre Circulação de Mercadorias e Serviços (ICMS), dos estados-membros aos municípios, segundo critérios ambientais. A recente implementação da política no Estado do Pará demanda verificar a adequação de seus resultados práticos aos pressupostos teóricos e finalidades declaradas. Para tanto, foi realizada análise dos impactos financeiros relativos aos municípios integrantes da Lista de Municípios Prioritários do Ministério do Meio Ambiente, grupo diretamente relacionado ao objetivo de controle e redução das taxas de desmatamento no Estado. Ao comparar os valores repassados a esses entes municipais desde a inserção do critério ambiental (2014-2016) e os que receberiam caso se mantivesse a divisão de receitas anterior, constatou-se que os municípios integrantes da lista saíram beneficiados com a nova forma de repartição, o que

10 presente trabalho foi realizado com apoio da CAPES, Coordenação de Aperfeiçoamento de Pessoal de Nível Superior - Brasil, no âmbito do Programa Capes/Cofecub, bem como do Programa "Investissements d'avenir" da Agence nationale de la recherche française (Ceba, réf. ANR-10-LABX-25-01) e do Programa Institucional de Bolsas de Iniciação Científica da Universidade Federal do Pará. 2 Doutora e Mestre em Direito pela Université Toulouse 1 -Capitole. Mestre em Direito Tributário pela Universidade de Paris I, Panthéon-Sorbonne. Mestre em Instituições jurídico-políticas pela Universidade Federal do Pará. Professora da Universidade Federal do Pará e do Centro Universitário do Estado do Pará. Université des Antilles et de la Guyanne - UAG. Pesquisadora do Centre National des Recherches Scientifiques - CNRS e do Laboratoire Caribéen de Sciences Sociales - LC2S. Coordenadora da Rede de Pesquisas Junction Amazonian Biodiversity Units Research Networking Program - Jambu RNP e do Grupo de Pesquisas Biodiversidade, Sociedade e Território na Amazônia - BEST Amazônia.

3 Doutor em Geografia pela Université des Antilles et de la Guyanne - UAG. Pesquisador do Centre National des Recherches Scientifiques - CNRS e do Laboratoire Caribéen de Sciences Sociales LC2S. Co-coordenador da Rede de Pesquisas Junction Amazonian Biodiversity Units Research Networking Program - Jambu RNP. 4 Bacharel em Direito pela Universidade Federal do Pará. Ex-Bolsista PIBIC/CNPQ. Membro do Grupo de Pesquisas Biodiversidade, Sociedade e Território na Amazônia - BEST Amazônia. 
contraria as diretrizes básicas de compensação e incentivo proporcionadas pelo ICMS Verde, bem como seu objetivo central de redução do desmatamento. As alterações na composição do critério ambiental realizadas em 2017 mantiveram esse tratamento benéfico, em meio à contínua degradação do ecossistema amazônico, o que demanda a reavaliação da política, de modo a aproximá-la dos objetivos estabelecidos em sua concepção, bem como conformá-la a partir de seus fundamentos teóricos. 


\section{THE IMPACT OF THE GREEN ICMS ON THE PRIORITY MUNICIPALITIES OF THE STATE OF PARÁ // Lise Tupiassu, Jean-Raphaël Gros-Désormaux, Luiz Paulo de Sousa Leão Fadel}

\author{
Keywords \\ environmental taxation / Green ICMS / priority \\ municipalities / State of Pará
}

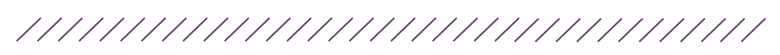

\begin{abstract}
The Green ICMS consists on the dimensioning of the financial transfers derived from the partition of the product of the collection of goods and services tax (ICMS), from the member states to the municipalities, according to environmental criteria. The recent implementation of the policy in the State of Pará requires the verification of the adjustment of its practical results with its theorical tenets and declared purposes. For this purpose, an analysis of the financial impacts on the municipalities included in the List of Priority Municipalities of the Ministry of the Environment, a group directly related with the objective of control and reduction of rates of deforestation in the State, was carried out. By comparing the transferred values to these municipalities since the insertion of environmental criteria (2014-2016) to those which would be received had the previous form of division remained, it was verified that they benefited by the new form of partition, contradicting its own guidelines of compensation and incentive, as well as its main objective of deforestation reduction. The changes on the composition of the environmental criteria introduced in 2017 reinforced this situation, as the degradation of the Amazonian ecosystem continues, demanding the policy's re-evaluation, in order to approximate it to the objectives established on its conception, as well as to conform it through its theoretical foundations.
\end{abstract}




\section{Introdução}

Decorre do direito ao meio ambiente ecologicamente equilibrado, tal qual reconhecido por nossa ordem constitucional - notadamente, em razão de sua natureza pública e, por conseguinte, indisponível -, o dever fundamental de atuação estatal em sua concretização, mediante a implementação de políticas públicas. 0 poder público pode se utilizar de diversos instrumentos para a defesa e preservação do meio ambiente - dentre os quais, os de natureza econômica, tributária e financeira.

A obrigação de proteção e promoção do direito a um meio ambiente equilibrado é, ainda, compartilhada por todos os entes federativos, independentemente da esfera político-administrativa a qual pertençam a proteção e preservação ambiental é de competência comum da União, estados-membros e municípios -, razão pela qual devem agir de forma cooperada nesse âmbito. Nesse contexto, destaca-se política pública que, inserida no desenho cooperativo do federalismo brasileiro, é exemplo do emprego de mecanismo de natureza financeira para a consecução de finalidades ambientais - qual seja, o ICMS Verde (também conhecido como ICMS Ecológico).

Em síntese, tal instituto consiste na modulação, por parte dos Estados-membros, dos critérios de distribuição da cota-parte da arrecadação do Imposto sobre Circulação de Mercadorias e Serviços (ICMS) pertencente aos municípios, como instrumento de política pública ambiental, mediante a introdução de critérios de matiz ecológica de repartição de receitas.

Cada estado que implementa o ICMS Verde estabelece, em meio aos necessários debates políticos, ínsitos ao processo legislativo, os critérios de dimensionamento de repasses financeiros que melhor se adequem às particularidades naturais de sua região (Tupiassu, 2006, p. 173). No Estado do Pará, a recente incorporação dessa política apresentou características próprias, voltadas especificamente para a redução e controle do desmatamento (Oliveira \& Tupiassu, 2014, p. 3), devido ao processo histórico de exploração econômica do espaço amazônico, razão pela qual é necessário realizar análise metódica dos resultados dessa experiência.
No presente trabalho, far-se-á exame da adequação dos impactos dessa política em relação a seus fundamentos teóricos e objetivos esperados, notadamente: promoção de justiça fiscal, a partir da redistribuição de receitas dos municípios produtores de externalidades negativas para os que demonstrem maiores preocupações com a preservação dos bens ambientais, geradores de externalidades positivas; e, ainda, de incentivo de condutas compatíveis com o objetivo de redução do desmatamento, a partir do fomento à participação dos entes municipais nessa tarefa.

O estudo se limitará ao exame dos repasses financeiros destinados aos municípios paraenses que integram a Lista de Municípios Prioritários do Ministério do Meio Ambiente (MMA), os quais, por possuírem altas taxas históricas de desmatamento, constituem grupo de análise especialmente ligado às finalidades de redução do desmatamento expressas pela norma de criação do ICMS Verde no Pará.

O tratamento a que esses municípios deveriam ser submetidos, à luz das finalidades e fundamentos da política, consideradas as especificidades do combate ao desmatamento no cenário amazônico, é tema que suscita relevantes considerações. Busca-se determinar qual foi o impacto financeiro decorrente da implementação do ICMS Verde no Estado do Pará em relação a esse grupo de municípios, para se compreender como essa política se manifestou no estado, em seus efeitos concretos.

Nesse ensejo, será necessária exposição, embora breve, dos fundamentos teóricos e base normativa do ICMS Verde. Em seguida, será realizado um relato do contexto da implementação da política no Estado do Pará, explicitando-se os instrumentos normativos que the deram forma, oportunidade em que serão expostos os critérios adotados na experiência paraense. Por fim, tratar-se-á dos municípios prioritários, analisando-se o impacto em seus repasses financeiros decorrente do ICMS Verde, a partir de comparação entre os valores que lhes foram efetivamente repassados desde a implementação da política e o montante que lhes seria repassado caso a forma de distribuição anterior fosse mantida. 


\section{Fundamentos teóricos e base constitucional do ICMS Verde}

A necessidade de distribuição espacial do poder leva à formação de diversas formas de organização do Estado, com base na variação no grau de descentralização entre as esferas político-administrativas. Dentre os modelos existentes, em contraposição ao Estado Unitário, ${ }^{5}$ destaca-se a Federação, em que coexistem um poder central, a quem se atribui exclusivamente a soberania - a não sujeição do poder estatal a qualquer outro -, e entidades descentralizadas, dotadas de autonomia, a qual somente se desenvolve dentro dos limites traçados pela soberania.

Embora a formação de uma Federação exija a transferência, por parte das entidades descentralizadas, de parcela de poder em favor do poder central, conserva-se uma competência própria, essencial para a manutenção de sua autonomia, que deve ser compreendida em seus aspectos políticos, administrativos e financeiros. Observa-se ainda que as dimensões da autonomia dos entes descentralizados são indissociáveis. Não há como se conceber a autonomia político-administrativa sem os recursos financeiros necessários para sua concretização; por sua vez, não há propósito na previsão de formas próprias de obtenção de receita ao ente federativo, sem que se assegure a este uma esfera particular de competência. Assim, sob a perspectiva do federalismo fiscal a dimensão financeira do federalismo -, para que os entes descentralizados possam exercer plenamente sua autonomia, de modo que cumpram suas funções atribuídas pelo texto constitucional, ofertando bens e prestando serviços públicos, são necessárias fontes de receita constitucionalmente previstas. ${ }^{6}$

5 "Se existe unidade de poder sobre o território, pessoas e bens, tem-se Estado Unitário. Se, ao contrário, o poder se reparte, se divide, no espaço territorial (divisão espacial de poderes), gerando uma multiplicidade de organizações governamentais, distribuídas regionalmente, encontramo-nos diante de uma forma de Estado composto, denominado Estado Federal ou Federação de Estados" (Silva, 2015, p. 100-101).

6 Demais disso, os bens e serviços públicos são prestados de forma mais eficiente por meio de uma estrutura administrativa descentralizada, em que melhor se considere a extensão espacial dos benefícios auferidos pela atividade estatal (Conti, 2001, p. 26) - por exemplo, os serviços de iluminação pública e de coleta de lixo são melhor providos pelas autoridades locais, em razão da limitação territorial de seus benefícios.
As fontes de arrecadação dos entes federativos podem ser próprias ou indiretas. A primeira hipótese corresponde ao mecanismo de repartição das fontes de receita, como ocorre com a discriminação constitucional da competência para a instituição de tributos entre os entes federativos. Por sua vez, tem-se uma fonte indireta com a repartição de recursos após a sua arrecadação, por meio de transferências intergovernamentais. Por exemplo, a previsão constitucional de repartição da arrecadação de um tributo instituído por um ente, em favor de outros entes da Federação (participação direta na arrecadação), ou a destinação de parcela da arrecadação de tributo para a formação de fundos, com posterior distribuição aos entes beneficiados, segundo critérios previamente definidos (participação indireta na arrecadação) (Conti, 2001, p. 36-38).

A forma com a qual a Constituição da República estrutura a Federação brasileira revela traços de federalismo dualista, ao fixar campos de atuação exclusiva dos entes de acordo com o nível de administração em que se encontram; toma-se como exemplo a discriminação constitucional - e portanto, rígida - de competências tributárias, excludentes da esfera de tributação de outros entes, quanto à instituição de impostos.

Contudo, é sua dimensão cooperativa que prepondera (Conti, 2001, p. 24), sobretudo no que refere às transferências governamentais, que assumem grande importância na efetivação da autonomia financeira dos entes e na promoção do equilíbrio federativo. Sobressai do texto constitucional uma exigência de solidariedade na atuação dos entes da Federação, os quais devem cooperar entre si para a consecução das finalidades constitucionalmente estabelecidas - cooperação que, em seu aspecto financeiro, manifesta-se por meio das transferências de receitas entre as unidades federativas.

As principais transferências intergovernamentais estão previstas nos artigos 157 a 159 da Constituição Federal e compreendem mecanismos de cooperação vertical, em que as transferências de receitas ocorrem entre entes federativos de graus diversos: da União para os Estados, da União para os municípios e dos Estados para os entes municipais.

A determinação constitucional de destinação de parcela do produto da arrecadação do ICMS para os mu- 
nicípios é exemplo de transferência intergovernamental, com participação direta dos entes municipais nas receitas de tributo de competência estadual. Segundo o artigo 158, inciso IV, da Constituição Federal (1988), $25 \%$ dos valores arrecadados a título de ICMS deve ser repassado aos entes municipais, de acordo com os seguintes critérios: três quartos, no mínimo, devem ser distribuídos na proporção do valor adicionado fiscal das operações realizadas pelos entes municipais; e até um quarto, de acordo com o que dispuser a lei estadual. O valor adicionado fiscal consiste, em síntese, na diferença entre as notas fiscais de compra e as notas fiscais de venda do município ${ }^{7}$, o que, a grosso modo, corresponde à capacidade de contribuição do ente municipal para a arrecadação de ICMS.

Desse modo, ao eleger o valor adicionado fiscal, indicador de natureza contábil, como o critério principal de distribuição de receitas, o texto constitucional privilegiou os municípios mais populosos e mais desenvolvidos economicamente, que possuem maior capacidade de geração de receitas a partir da arrecadação do ICMS, decorrente da incidência desse imposto sobre as operações de circulação de mercadorias e serviços em suas respectivas bases territoriais (Tupiassu, 2006, p. 190-191). É forma de retribuição das receitas obtidas pelos Estados-membros a partir da tributação de atividades produtivas desenvolvidas no município, hipótese de aplicação de princípio de justiça comutativa.

A discriminação do repasse das receitas do ICMS aos municípios segundo o critério do valor adicionado fiscal encontra-se em descompasso com a ampla proteção constitucional conferida ao meio ambiente. Os municípios que mais se beneficiam com a divisão segundo esse critério são aqueles que possuem maiores

7 A Lei Complementar n. 63 , em seu artigo $3^{\circ}$, parágrafo $1^{\circ}$, assim define Valor Adicionado: "O valor adicionado corresponderá, para cada município, ao valor das mercadorias saídas, acrescido do valor das prestações de serviços, no seu território, deduzido o valor das mercadorias entradas, em cada ano civil" (Lei Complementar n. 63, 1999). Cumpre ressaltar que no cálculo do valor adicionado fiscal são computadas operações que constituam o fator gerador do imposto, ainda que o crédito tributário seja diferido, reduzido ou excluído em virtude de isenção ou outros benefícios, incentivos ou favores fiscais. Além disso, as imunidades previstas nas alíneas "a" e "b" do inciso X do $\S 2^{\circ}$ do art. 155, e a alínea "d" do inciso VI do art. 150, da Constituição, não interferem no cômputo desse indicador. condições de desenvolver atividades economicamente produtivas, as quais, em regra, resultam em externalidades negativas. Por outro lado, os municípios que arcam com a responsabilidade de preservar o bem natural, produzindo externalidades positivas, das quais todos se beneficiam, têm restrições à sua capacidade de desenvolvimento econômico - por exemplo, restrição de uso de parcela de seu solo, decorrente da instituição de Unidade de Conservação - e, consequentemente, recebem menores repasses financeiros dos Estados-membros (Scaff \& Tupiassu, 2005, p. 734).

Note-se que as externalidades são influências, positivas ou negativas, exercidas por agentes econômicos em outros agentes, sem que seus efeitos sejam objeto de avaliação ou compensação pelo mercado (Pigou, 1929; Marshall, 1920; Tupiassu, 2010, p. 114). Por exemplo, o despejo de rejeitos industriais em um curso de água acarreta graves custos ambientais e sociais - como a destruição do ecossistema aquático, inviabilização de atividades econômicas tradicionais da região e prejuízo à saúde da população ribeirinha -, que não são computados naturalmente no processo produtivo, sem que haja qualquer compensação automática por parte do agente poluidor.

Daí surge a necessidade de intervenção estatal para corrigir falhas de mercado (Lévêque, 1999), de modo a evitar que os lucros individuais decorrentes de atividades nocivas ao meio ambiente sejam auferidos a partir da socialização dos prejuízos. Tal ingerência pode se operar por meio da internalização das externalidades negativas por quem as emite, em aplicação do princípio do poluidor-pagador, ou da observância de seu corolário, o princípio do protetor-recebedor, para compensar financeiramente os agentes que produzam externalidades positivas em razão dos benefícios coletivos de sua conduta.

Não houve qualquer intenção por parte do legislador constitucional, ao fixar o valor adicionado fiscal como critério majoritário de repartição das receitas da arrecadação do ICMS, em incorporar qualquer dessas preocupações. Contudo, há permissivo que abre a possibilidade de fixação de critérios alternativos - qual seja, a previsão de distribuição de $25 \%$ da cota-parte da arrecadação do ICMS pertencente aos municípios segundo critérios estabelecidos pela legislação estadual. 
Ante a oportunidade aberta pelo texto constitucional, diversos Estados-membros passaram a adotar critérios ecológicos de repartição de receitas entre os entes municipais, implementando política pública ambiental que se convencionou denominar ICMS ${ }^{8}$ Ecológico ou Verde. Em um primeiro momento, com a experiência inicial do Estado do Paraná, ${ }^{9}$ o surgimento da política decorreu das demandas de municípios que possuíam Mananciais Hídricos e Unidades de Conservação, como forma de compensá-los pelas restrições econômicas decorrentes da afetação de parcela de seu território à preservação ambiental. Contudo, passou-se com o tempo a reconhecer importante viés incentivador da política, com a adoção de critérios diversos, afetos tanto à seara ambiental quanto à social (Oliveira, 2014, p. 80).

Vislumbra-se, dessa forma, duas dimensões principais de atuação do ICMS Verde: compensatória e incentivadora. Trata-se de forte instrumento econômico extrafiscal para a concretização da finalidade constitucional de preservação ambiental, promovendo justiça fiscal e influenciando as condutas dos entes municipais, que naturalmente buscam obter aumentos de receita, ao se adequar aos critérios legais. É forma de intervenção positiva do Estado, como fator de regulação não-coercitiva, que se assemelha a um incentivo fiscal intergovernamental (Tupiassu, 2006, p. 195).

\section{O ICMS Verde no estado do Pará}

A Constituição do Estado do Pará (1989) prevê expressamente, desde sua promulgação, em seu art. 225, tratamento especial aos municípios que tenham parte de seus territórios afetados a unidades de conservação, quanto aos créditos das parcelas de receita oriunda da arrecadação do ICMS. Contudo, esse dispositivo constitucional, bastante inovador à época - quando sequer havia ocorrido a pioneira implementação do ICMS Verde no Estado do Paraná -,

8 Embora a denominação utilizada faça referência à espécie de imposto, trata-se, a rigor, de um instrumento de natureza predominantemente financeira - e não tributária -, por operar em momento posterior ao da arrecadação de receitas pelo ente estatal.

9 A implementação da política se deu no ano de 1991, a partir da Lei Estadual n 9.491, da Lei Complementar n 59 e do Decreto Estadual $n^{\circ} 974 / 91$ manteve-se inaplicável por 23 anos, devido à falta de regulamentação legal decorrente da inércia do legislador estadual.

Embora alguns projetos de lei tenham sido apresentados anteriormente, somente se percebeu vontade política de regulamentá-lo em 2009, a partir da inclusão, pelo Poder Executivo estadual, da elaboração, aprovação e implementação do ICMS Ecológico no Estado como ação prioritária no Plano de Prevenção, Controle e Alternativas ao Desmatamento do Estado do Pará (PPCAD-PA) $)^{10}$ (Tupiassu \& Haber, 2014, p. 299).

Finalmente, após apresentação de projeto de lei pelo Governador do Estado, foi aprovada a Lei Estadual n. 7.638, de 12 de julho de 2012, que alterou os critérios de distribuição das receitas do ICMS pertencentes aos municípios, constantes da Lei Estadual n. 5.645/91. A inclusão do critério ecológico se deu com a diminuição, gradual, anual e sucessiva, de parcela da divisão de receitas realizada sob o critério igualitário - que anteriormente compunha $15 \%$ do total do valor repassado. De acordo com o anexo único da lei, os critérios de repartição se estabilizaram em 2015, nos seguintes patamares: $75 \%$ do valor total do repasse de modo proporcional ao valor adicionado fiscal; 5\% de acordo com a proporção da população municipal; $5 \%$ na proporção da área municipal; $7 \%$ segundo o critério igualitário; e 8\% conforme o critério ambiental (Lei Estadual n. 7.638, 2012).

Como já ressaltado, a finalidade principal da política é reduzir e controlar o desmatamento nos municípios paraenses; em vista disso, não se seguiu a tendência dos demais estados brasileiros, de incluir critérios com aspectos socioambientais ${ }^{11}$ (Oliveira \& Tupiassu,

10 A instituição do PPCAD-PA se deu após a intensificação das ações de fiscalização e controle por parte do governo federal, devido ao recrudescimento das taxas de desmatamento na região amazônica nos primeiros anos da década de 2000, levando ao lançamento do Plano de Ação para Prevenção e Controle do Desmatamento na Amazônia Legal (PPCDAM) pela União.

11 São exemplos de critérios adotados em outras unidades da federação: criação de Unidades de Conservação, controles de queimadas, Mananciais de Abastecimento, Política municipal de meio ambiente (critérios exclusivamente ambientais); gastos com saúde; avaliação dos alunos por programa de avaliação da aprendizagem; taxa de cobertura vacinal (critérios socioambientais) (Oliveira, 2014, p. 81). 
2014, p. 286-287). Em um primeiro momento, anterior à regulamentação da lei instituidora, o critério ecológico adotado era composto por dois fatores, fixados pelo artigo $2^{\circ}$ da referida norma: a existência, no território do município, de unidades de conservação e outras áreas protegidas; ${ }^{12}$ e sua participação na implementação e na gestão de tais áreas (Oliveira \& Tupiassu, 2014, p. 288).

Além disso, a Lei Estadual n. 7.638/2012 estabeleceu, em seu artigo $3^{\circ}$, uma condição formal para o gozo do tratamento especial a que se refere o constituinte estadual: a manutenção de Sistema Municipal do Meio Ambiente próprio, de natureza participativa, estruturado em conformidade com certos requisitos. ${ }^{13}$ Nesse ponto, percebe-se a clara intenção do legislador estadual de incentivar a implementação de uma gestão ambiental local bastante avançada, com uma estrutura completa e qualitativamente satisfatória (Oliveira \& Tupiassu, 2014, p. 287). A condição encontra ressonância nos requisitos previstos pela Lei Complementar n. 140/2011 para o exercício pleno pelos municípios de sua competência administrativa em matéria ambiental, constitucionalmente atribuída.

A regulamentação inicial da lei instituidora se deu a partir do Decreto n. 775/2013, o qual incluiu dois novos indicadores de natureza ambiental para determinação do critério ecológico, quais sejam a cobertura vegetal e redução de desmatamento e a inserção do

12 Conforme o parágrafo único do artigo $2^{\circ}$ da Lei Estadual n. 7.638 (2012), consideram-se unidades de conservação as Unidades de Proteção Integral e as Unidades de Uso Sustentável, previstas no Sistema Nacional de Unidades de Conservação da Natureza, bem como as demais áreas protegidas integrantes do Sistema Estadual de Biodiversidade e Áreas Protegidas, tais como as estradas cênicas, os rios cênicos, as reservas de recursos naturais, as áreas de populações tradicionais, as áreas e terras indígenas, e as áreas de preservação permanente e de reserva legal, conforme dispuser o regulamento.

13 De acordo com o dispositivo, o Sistema Municipal deve ser composto, no mínimo, por: a) Conselho Municipal do Meio Ambiente, de caráter deliberativo e composição socialmente paritária; b) Fundo Municipal do Meio Ambiente; c) órgão público administrativo executor da Política Municipal do Meio Ambiente, dotado de recursos humanos, materiais e financeiros adequados e suficientes para exercer suas funções, em especial, a implantação do processo de planejamento e o Plano Municipal do Meio Ambiente, visando consolidar a Agenda 21 Local; d) demais instrumentos de política pública e participativa necessários à plena execução da Política Municipal do Meio Ambiente (Lei Estadual n. 7.638, 2012). território do município no Cadastro Ambiental Rural (CAR). Desse modo, a repartição passou a se orientar da seguinte forma: I) 25\%, conforme a porcentagem do território municipal ocupado por Áreas Protegidas e de uso especial; II) 25\%, ante a existência de um estoque mínimo de cobertura vegetal e a redução do desmatamento nos Municípios; III) 50\%, considerando a porcentagem da área cadastrável do Município inserida no CAR (Decreto n. 775, 2013).

Contudo, a partir do ano de 2017, passou-se a utilizar nova metodologia de dimensionamento dos valores da cota-parte pertencente aos municípios, estabelecida por meio da Portaria Semas/PA de $n^{\circ} 1.272$ de 21 de julho de 2016, seguida do Decreto 1.696, de 07 de fevereiro de 2017. Desde então, o valor do repasse é calculado a partir de quatro fatores, de pesos distintos e variáveis anualmente, ${ }^{14}$ com a justificativa de existir a necessidade de se incluir uma abordagem qualitativa e inclusiva e de oportunizar novas dimensões para a agenda do ICMS Verde (Secretaria de Estado de Meio Ambiente e Sustentabilidade [Semas], 2016).

\section{Os municípios prioritários e o ICMS Verde}

O recrudescimento das taxas de desmatamento na região amazônica nos primeiros anos da década passada levou o Governo Federal a constituir o Grupo Permanente de Trabalho Interministerial (GPTI), composto por diversos ministérios e coordenado pela Casa Civil. Dessa iniciativa, surgiu o Plano de Ação de Prevenção e Controle do Desmatamento na Amazônia (PPCDAM), lançado em 2004, tendo por objetivo a redução contínua e consistente do desma-

14 Conforme a última atualização, realizada pela Portaria Semas/ PA n. 1.310/17, os fatores e pesos são os seguintes: Fator 1, denominado de Regularização Ambiental, composto pelos indicadores CAR, Área de Preservação Permanente (APP), Reserva Legal (RL) e a Área Degradada (AD), de peso de 44,565\%; Fator 2, denominado de Gestão Territorial, composto pelos indicadores Áreas Protegidas de Uso Restrito, Áreas Protegidas de Uso Sustentável, Desflorestamento e Desflorestamento em Áreas Protegidas, com peso de 29,871\%; Fator 3, denominado de Estoque Florestal, formado por um único indicador (Remanescente Florestal), apresentando um peso de 14,223\%\%; Fator 4, denominado de Fortalecimento da Gestão Ambiental Municipal, também composto por um único indicador (Capacidade de Exercício da Gestão Ambiental), com peso de $11,341 \%$ (Portaria Semas/PA, 2017). 
tamento e a criação de condições para se estabelecer um modelo de desenvolvimento sustentável na Amazônia Legal (Ministério do Meio Ambiente [MMA], 2016a). Encontra-se estruturado em três eixos temáticos: a) Ordenamento Fundiário e Territorial; b) Monitoramento e Controle Ambiental; e c) Fomento às Atividades Produtivas Sustentáveis.

Em sua primeira fase (2003-2007), houve a criação de cerca de 480 mil km² de unidades de conservação, bem como avanços significativos na área de comando e controle, com aumento da fiscalização de campo, prisão de autoridades e produtores envolvidos com o desmatamento ilegal e o lançamento dos sistemas de monitoramento Deter e SAD. A partir dessas medidas, houve redução do incremento do desmatamento, de 19,6 mil km² (média de 1996-2005) para 12,6 mil km² (média de agosto 2005 - julho 2008) (Whately, 2013, p. 18).

Contudo, a diminuição mais drástica do desmatamento amazônico se deu a partir do início de 2008 , com a implementação da segunda fase do plano; em especial, em decorrência de ações afetas ao eixo Monitoramento e Controle (Whately, 2013, p. 18). Dentre as medidas adotadas, ${ }^{15}$ sobressai a edição do Decreto n. 6.321, de 21 de dezembro de 2007, que instituiu lista de municípios considerados prioritários para ações de controle. O objetivo foi municipalizar o combate ao desmatamento, focalizando os esforços do governo federal nos municípios em processo de desflorestamento mais intenso.

Os territórios dos municípios integrantes da lista são submetidos a medidas de integração e aperfeiçoamento das ações de monitoramento e controle de órgãos federais, de ordenamento fundiário e territorial e de incentivo a atividades econômicas ambientalmente sustentáveis (MMA, 2016b), bem como a restri-

15 Além da instituição de Lista de Municípios Prioritários, destaca-se a restrição ao credito rural, a partir da Resolução do Conselho Monetário Nacional $n^{\circ} 3.545 / 2008$, com a exigência de regularidade ambiental e fundiária para a concessão de financiamento; a responsabilização da cadeia produtiva da carne, com a regulamentação da Lei de Crimes Ambientais e celebração de Termo de Ajuste de Conduta entre o Ministério Público e grandes frigoríficos; publicação pelo Ibama de áreas embargadas em decorrência do desmatamento; fortalecimento de ações de fiscalização, com o lançamento de operações como a Arco Verde e Boi Pirata, envolvendo diversos órgãos (Whately, 2013, p. 18-19). ções administrativas e econômicas significativas. ${ }^{16}$ Os resultados da política foram substanciais: estima-se que tenha sido evitado o desmatamento de 11.359 $\mathrm{Km}^{2}$, de 2008 a 2011, área equivalente à do estado de Sergipe, sobretudo em razão do aumento da fiscalização e melhoria na aplicação da lei (Assunção \& Rocha, 2014, p. 6).

Segundo o art. $2^{\circ}$ do Decreto n. 6.321/2007, o MMA é responsável pela edição anual de portaria com a lista de municípios, considerados os seguintes critérios de inclusão, os quais também devem ser fixados por meio de portaria do ministério: a) área total de floresta desmatada no território do município; b) área total de floresta desmatada nos últimos três anos; c) aumento da taxa de desmatamento em pelo menos três, dos últimos cinco anos.

Devem ainda ser editados anualmente critérios para saída dos municípios da lista, também por meio de portaria do órgão ministerial. Cumpridos os requisitos para a retirada, cessam-se as restrições e os municípios excluídos passam a compor lista daqueles considerados com processo de desmatamento sob controle e monitorado. ${ }^{17}$

16 Dentre as quais se destacam: proibição de emissão de novas autorizações de desmatamento em dimensão superior a 5 hectares; possibilidade de recadastramento de imóveis rurais pelo Instituto Nacional de Colonização e Reforma Agrária; embargo de áreas desmatadas ilegalmente; intensificação da fiscalização; publicação pelo Ibama da lista de imóveis com cobertura vegetal monitorada/ embargados, com coordenadas geográficas; proibição de concessão de crédito por agências oficiais para atividades agropecuárias ou florestais em imóvel rural que descumpra embargo (Neves, 2015, p. 7).

17 Contudo, desde a edição da Portaria n 412/2013 do MMA, que excluiu os municípios de Brasnorte, Feliz Natal e Marcelândia (MT) e Brasil Novo e Tailândia (PA), não houve saída de municípios da lista ou atualização dos critérios de exclusão, fixados da seguinte forma, pela Portaria 411/2013 do MMA (2013): "Art. $1^{\circ}$ Ficam estabelecidos os requisitos que vigorarão no ano de 2013, para que os municípios localizados no bioma Amazônia possam ser considerados com desmatamento monitorado e sob controle: a) possuam $80 \%$ (oitenta por cento) de seu território, excetuadas as unidades de conservação de domínio público e terras indígenas homologadas, com imóveis rurais devidamente monitorados por meio de Cadastro Ambiental Rural-CAR; b) o desmatamento ocorrido no ano de 2012 tenha sido igual ou menor que 40 $\mathrm{km}^{2}$; c) as médias do desmatamento dos períodos de 2010-11 e 2011-12 seja inferior a 60\% em relação à média do período de 2007-08, 2008-09 e 2009-2010". 
Atualmente, 15 municípios do Estado do Pará integram a lista. São os seguintes: São Félix do Xingu, Santa Maria das Barreiras, Rondon do Pará, Novo Repartimento, Novo Progresso, Cumaru do Norte e Altamira (incluídos pela Portaria $n^{\circ}$ 28/2008); Pacajá, Marabá e Itupiranga (Portaria $n^{\circ}$ 102/2009); Moju (Portaria $n^{\circ}$ 175/2011); Senador José Porfírio e Anapu (Portaria $n^{\circ}$ 323/2012); Itaituba e Portel (Portaria n 361/2017).

Ao examinar a situação dos municípios prioritários à luz dos fundamentos do ICMS Verde, a partir de ambas as suas funções (compensatória e incentivadora), chega-se à conclusão inicial de que deveriam receber menor volume de repasses financeiros sob a nova sistemática de repartição de receitas.

Como o processo de desflorestamento é mais acentuado em seus territórios, tornam-se grandes produtores de externalidades negativas, frustrando suas expectativas de se beneficiar com a função compensatória da política. Ademais, quanto ao viés incentivador desta, somente poderiam aumentar suas receitas ao se adequar aos critérios ecológicos definidos, que deveriam ser suficientemente rígidos para que a função indutora de condutas não fosse frustrada. De início, portanto, veriam sua participação na cota-parte da arrecadação do ICMS ser reduzida, até que atingissem os indicadores ambientais exigidos, a partir de seu esforço ambiental.

Há, contudo, um contraponto, procedente das demandas dos gestores públicos desses municípios, que defendem ser contraproducente retirar recursos financeiros das administrações municipais no momento em que seriam essenciais para a implementação de ações de combate do desmatamento. Além disso, argumenta-se que os critérios ambientais não levariam em consideração as limitações dos municípios quanto à gestão e fiscalização de parcela significativa de seu território, sujeito a restrições decorrentes da delimitação, por parte da União e Estados-membros, de espaços territoriais especialmente protegidos, tais como as unidades de conservação. ${ }^{18}$

18 A validade de tais argumentos foi testada através de pesquisa empírica com os dados do investimento em gestão ambiental dos Municípios e possibilidades de ação em seu âmbito territorial (Fadel, 2017; Nóbrega, 2018), verificando-se falhas no engajamento ambiental municipal, ainda que diante de um repasse maior de recursos.
Apesar disso, em vista do objetivo central assumido pela política no Estado do Pará, de redução do desmatamento mediante o fomento à participação dos municípios no cumprimento do dever estatal de proteção ambiental, maior parcela de repasses deveria ser direcionada aos entes municipais provedores de serviços ecossistêmicos e não àqueles que registrem altas taxas de desmatamento, tais como os municípios prioritários (Ferreira, 2016). Do contrário, não haveria incentivo financeiro a um maior engajamento municipal no combate às causas do desmatamento, uma vez que tais municípios não seriam induzidos a implementar ações para se adequar aos indicadores que compõem o critério ecológico.

Ademais, embora se reconheça que os municípios enfrentam limitações fáticas e jurídicas à sua atuação no combate ao desmatamento, não há como se afastar o dever fundamental estatal de concretização do direito fundamental ao meio ambiente ecologicamente equilibrado - tarefa que deve ser desempenhada por todos os entes federativos, em cooperação, mediante a utilização de instrumentos como o próprio ICMS Verde.

\section{$5 \quad$ Análise dos repasses financeiros aos municípios prioritários do estado do Pará}

Como já exposto acima, o critério ecológico paraense tomou o lugar de parte do critério igualitário, que antes regia o repasse de $15 \%$ da arrecadação do ICMS pertencente aos municípios, de forma anual, gradual e sucessiva. ${ }^{19}$

19 De acordo com o que dispõem os incisos do art. $3^{\circ}$ do Decreto $n$. 775/2013, o cálculo e repasse da parcela da arrecadação do ICMS distribuída sob o ICMS Verde deve seguir os seguintes percentuais e cronograma: 2\% referente ao ano-base 2012, calculado em 2013 e repassado em 2014; 4\% referente ao ano-base 2013, calculado em 2014 e repassado em 2015; 6\% referente ao ano-base 2014, calculado em 2015 e repassado em 2016; 8\% referente ao ano-base 2015, calculado em 2016 e repassado em 2017. Assim, as etapas da divisão de receitas segundo o critério ecológico se verificam em momentos distintos: os dados referentes aos indicadores ambientais que compõem o critério ecológico são aferidos em determinado ano; no seguinte, é efetuado o cálculo dos índices de repasse de cada município; por fim, no ano subsequente os valores são repassados aos entes municipais. 
A análise proposta neste estudo visou verificar o efeito financeiramente positivo ou negativo da introdução da política do ICMS Verde no Estado do Pará em relação aos municípios inscritos na lista dos considerados prioritários para ações de controle de desmatamento.

A metodologia utilizada consistiu em comparar os valores de ICMS efetivamente repassados aos municípios prioritários de 2014 até $2016,{ }^{20}$ sob os critérios ecológico e igualitário, e os valores que lhes seriam repassados no mesmo período exclusivamente sob o critério igualitário, caso a antiga forma de divisão de receitas ainda subsistisse. Para tanto, foram utilizados dados fornecidos pela Semas e Secretaria de Estado de Fazenda Pública [Sefa/PA], devidamente sistematizados nas Tabelas 1 e 2.

Tabela 1. Valores repassados aos municípios prioritários (2014-2016), sob os critérios igualitário e ecológico.

\begin{tabular}{|l|l|l|l|l|}
\hline MUNICÍPIOS & $\begin{array}{l}2014 \\
\text { Ecológico }(2 \%)+\text { Igualitá- } \\
\text { rio }(13 \%)\end{array}$ & $\begin{array}{l}2015 \\
\text { Ecológico (4\%)+ Igualitá- } \\
\text { rio (11\%) }\end{array}$ & $\begin{array}{l}2016 \\
\text { Ecológico (6\%)+ Igualitá- } \\
\text { rio (9\%) }\end{array}$ & Total 2014-2016 \\
\hline ALTAMIRA & $2.000 .925,87$ & $2.060 .440,03$ & $3.338 .404,73$ & $7.399 .770,63$ \\
\hline ANAPU & $2.128 .506,33$ & $2.566 .484,75$ & $2.869 .044,86$ & $7.564 .035,94$ \\
\hline CUMARU DO NORTE & $2.087 .006,30$ & $2.444 .436,83$ & $2.645 .894,92$ & $7.177 .338,05$ \\
\hline ITUPIRANGA & $2.041 .092,88$ & $2.365 .755,32$ & $2.568 .485,03$ & $6.975 .333,23$ \\
\hline MARABÁ & $2.029 .444,97$ & $2.325 .082,65$ & $2.472 .657,30$ & $6.827 .184,92$ \\
\hline MOJU & $1.888 .461,14$ & $2.080 .906,72$ & $2.142 .355,23$ & $6.111 .723,09$ \\
\hline NOVO PROGRESSO & $2.151 .210,51$ & $2.351 .441,71$ & $2.490 .408,43$ & $6.993 .060,65$ \\
\hline NOVO REPARTIMENTO & $1.998 .246,48$ & $2.289 .154,88$ & $2.480 .750,93$ & $6.768 .152,29$ \\
\hline PACAJÁ & $1.932 .758,55$ & $2.150 .691,21$ & $2.274 .291,97$ & $6.357 .741,73$ \\
\hline RONDON DO PARÁ & $1.887 .982,58$ & $1.798 .894,30$ & $1.722 .951,15$ & $5.409 .828,03$ \\
\hline STA M. DAS BARREIRAS & $1.926 .692,55$ & $2.137 .035,51$ & $2.207 .423,67$ & $6.271 .151,73$ \\
\hline SÃO FELIX DO XINGU & $2.252 .829,91$ & $2.800 .502,49$ & $3.189 .703,63$ & $8.243 .036,03$ \\
\hline SENADOR J. PORFíRIO & $2.255 .414,81$ & $2.791 .921,02$ & $2.793 .047,35$ & $7.840 .383,18$ \\
\hline
\end{tabular}

Fonte: Sefa/PA, 2018; Semas/PA, 2018.

Nota: dados trabalhados pelos autores. 
Tabela 2. Valores que seriam repassados aos municípios prioritários sob o critério igualitário (2014-2016), caso não houvesse a introdução do critério ecológico.

\begin{tabular}{|l|l|l|l|l|}
\hline MUNICÍPIOS & $\begin{array}{l}2014 \\
\text { Critério Igualitário }(15 \%)\end{array}$ & $\begin{array}{l}2015 \\
\text { Critério Igualitário } \\
(15 \%)\end{array}$ & $\begin{array}{l}2016 \\
\text { Critério Igualitário } \\
(15 \%)\end{array}$ & Total 2014-2016 \\
\hline ALTAMIRA & $1.888 .142,35$ & $2.028 .473,13$ & $2.084 .077,86$ & $6.000 .693,34$ \\
\hline ANAPU & $1.888 .142,35$ & $2.028 .473,13$ & $2.084 .077,86$ & $6.000 .693,34$ \\
\hline CUMARU DO NORTE & $1.888 .142,35$ & $2.028 .473,13$ & $2.084 .077,86$ & $6.000 .693,34$ \\
\hline ITUPIRANGA & $1.888 .142,35$ & $2.028 .473,13$ & $2.084 .077,86$ & $6.000 .693,34$ \\
\hline MARABÁ & $1.888 .142,35$ & $2.028 .473,13$ & $2.084 .077,86$ & $6.000 .693,34$ \\
\hline MOJU & $1.888 .142,35$ & $2.028 .473,13$ & $2.084 .077,86$ & $6.000 .693,34$ \\
\hline NOVO PROGRESSO & $1.888 .142,35$ & $2.028 .473,13$ & $2.084 .077,86$ & $6.000 .693,34$ \\
\hline NOVO REPARTIMENTO & $1.888 .142,35$ & $2.028 .473,13$ & $2.084 .077,86$ & $6.000 .693,34$ \\
\hline PACAJÁ & $1.888 .142,35$ & $2.028 .473,13$ & $2.084 .077,86$ & $6.000 .693,34$ \\
\hline RONDON DO PARÁ & $1.888 .142,35$ & $2.028 .473,13$ & $2.084 .077,86$ & $6.000 .693,34$ \\
\hline STA M. DAS BARREIRAS & $1.888 .142,35$ & $2.028 .473,13$ & $2.084 .077,86$ & $6.000 .693,34$ \\
\hline SÃO FELIX DO XINGU & $1.888 .142,35$ & $2.028 .473,13$ & $2.084 .077,86$ & $6.000 .693,34$ \\
\hline SENADOR J. PORFÍRIO & $1.888 .142,35$ & $2.028 .473,13$ & $2.084 .077,86$ & $6.000 .693,34$ \\
\hline
\end{tabular}

Fonte: Sefa/PA, 2018.

Nota: dados trabalhados pelos autores.

Ao comparar os dados constantes das duas tabelas, obtém-se as seguintes variações:

Gráfico 1. Variação percentual entre os valores que seriam repassados aos municípios prioritários sob o critério igualitário (2014-2016), caso não houvesse a introdução do critério ecológico, e os valores efetivamente repassados no período, sob os critérios igualitário e ecológico.

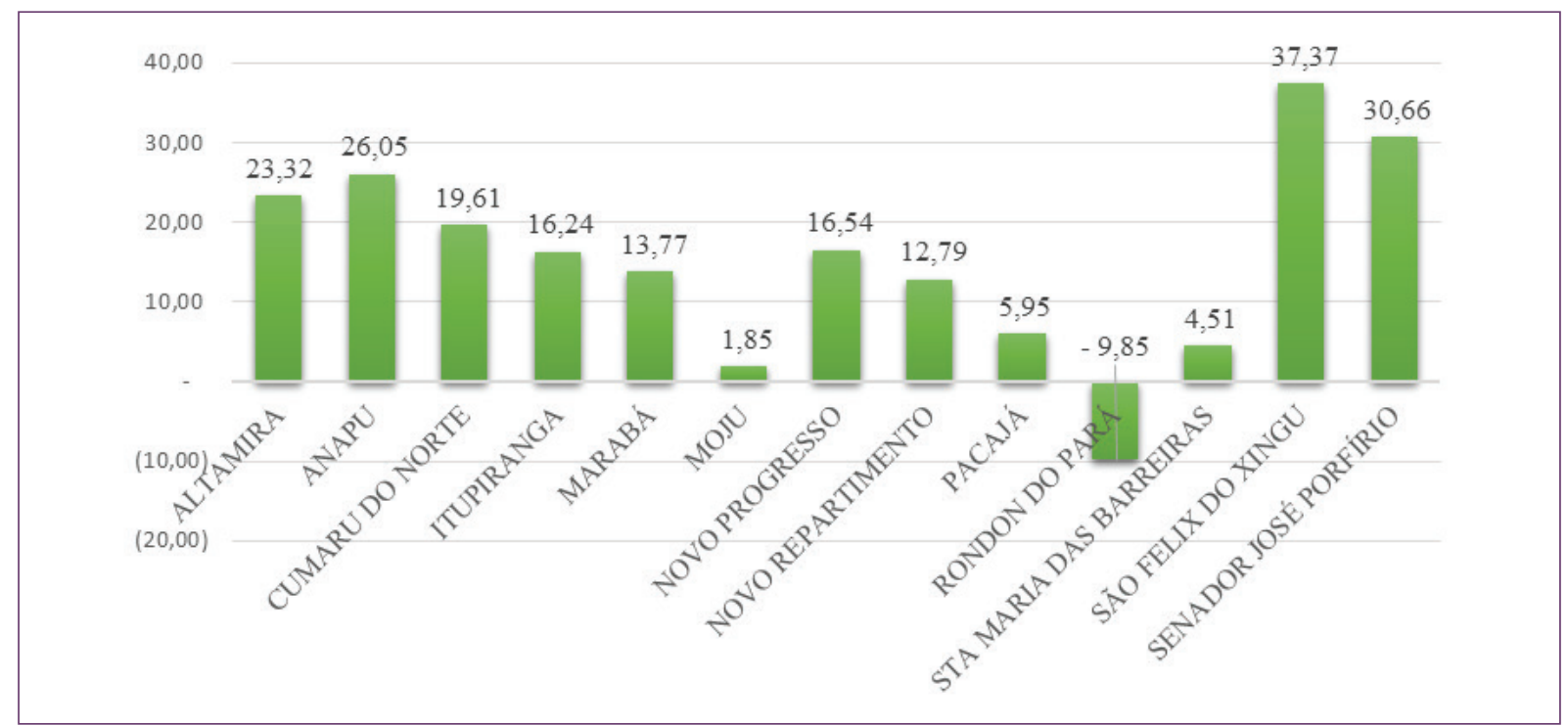

Fonte: Sefa/PA, 2018; Semas/PA, 2018.

Nota: dados trabalhados pelos autores. 
Constata-se que, após a introdução do critério ecológico, no período entre 2014 e 2016, à exceção de Rondon do Pará, todos os municípios prioritários paraenses saíram beneficiados. 0 município de São Félix do Xingu obteve o maior aumento de receita, recebendo cerca de $32 \%$ a mais, sob os critérios ecológico e igualitário, do que receberia exclusivamente sob o critério igualitário. 0 único município prioritário que perdeu receitas com a introdução do ICMS Verde foi Rondon do Pará, nesse período inicial de implementação, embora Moju, Pacajá e Sta. Maria das Barreiras não tenham registrado aumentos expressivos.

Contudo, o gráfico acima não leva em consideração a participação do critério ecológico no valor total repassado a cada município prioritário. Deve-se observar que tais municípios não constituem um conjunto homogêneo, possuindo marcantes diferenças populacionais e econômicas que refletem na composição dos repasses financeiros a título de participação na arrecadação de ICMS. Por exemplo, o peso do critério ecológico no montante total repassado não é o mesmo para municípios de Marabá, que abriga a terceira maior cidade do estado em população, com 233.462 habitantes, e Senador José Porfírio, com apenas 12.998 habitantes (Instituto Brasileiro de Geografia e Estatística [IBGE], 2010).

Como anteriormente observado, os municípios de maior população e atividade econômica são, geralmente, os maiores beneficiários da distribuição de receitas com base no critério do valor adicionado fiscal, eis que em seus territórios se verifica maior ocorrência de situações realizadoras das hipóteses de incidência do ICMS. Além disso, a sistemática de distribuição de receitas da cota parte da arrecadação de ICMS entre os municípios no Estado do Pará inclui um critério populacional, correspondente a $5 \%$ do valor total do repasse. São fatores que contribuem para que a participação do critério ecológico na cota parte da arrecadação do ICMS que cabe ao município de Marabá seja reduzida, se comparada a de Senador José Porfírio.

Em vista disso, foi realizada nova análise, dessa vez considerando o valor total repassado aos municípios prioritários, conforme a tabela e gráfico a seguir:

Tabela 3. Valor total repassado desde a introdução do critério ecológico (2014-2016), e o montante que seria repassado, caso não houvesse a introdução do critério ecológico.

\begin{tabular}{|l|l|l|l|l|l|}
\hline MUNICÍPIOS & Total 2014 & Total 2015 & Total 2016 & Total 2014-2016 & $\begin{array}{l}\text { Total 2014-2016 } \\
\text { sem o critério } \\
\text { ecológico }\end{array}$ \\
\hline ALTAMIRA & $30.089 .436,51$ & $37.194 .083,26$ & $43.691 .389,46$ & $110.974 .909,23$ & $109.575 .831,94$ \\
\hline ANAPU & $4.712 .803,31$ & $6.036 .736,03$ & $6.845 .655,49$ & $17.595 .194,83$ & $16.031 .852,23$ \\
\hline CUMARU DO NORTE & $6.344 .158,30$ & $7.205 .136,55$ & $7.852 .369,53$ & $21.401 .664,38$ & $20.225 .019,66$ \\
\hline ITUPIRANGA & $5.256 .588,30$ & $6.815 .669,71$ & $8.053 .712,34$ & $20.125 .970,35$ & $19.151 .330,46$ \\
\hline MARABÁ & $85.918 .029,54$ & $95.614 .109,32$ & $110.738 .544,73$ & $292.270 .683,59$ & $291.444 .192,01$ \\
\hline MOJU & $9.063 .083,28$ & $12.657 .672,31$ & $13.892 .653,79$ & $35.613 .409,38$ & $35.502 .379,62$ \\
\hline NOVO PROGRESSO & $9.063 .083,28$ & $10.320 .871,27$ & $11.476 .540,09$ & $30.860 .494,64$ & $29.868 .127,33$ \\
\hline NOVO REPARTIMENTO & $8.700 .559,95$ & $11.099 .804,96$ & $13.288 .625,36$ & $33.088 .990,27$ & $32.321 .531,32$ \\
\hline PACAJÁ & $5.981 .634,97$ & $7.399 .869,97$ & $8.859 .083,58$ & $22.240 .588,52$ & $21.883 .540,12$ \\
\hline RONDON DO PARÁ & $6.887 .943,30$ & $7.205 .136,55$ & $7.651 .026,73$ & $21.744 .106,58$ & $22.334 .971,89$ \\
\hline STA MARIA DAS BARREIRAS & $5.256 .588,30$ & $6.036 .736,03$ & $6.644 .312,69$ & $17.937 .637,02$ & $17.667 .178,63$ \\
\hline SÃO FELIX DO XINGU & $19.032 .474,90$ & $22.589 .076,75$ & $24.966 .508,27$ & $66.588 .059,92$ & $64.345 .717,23$ \\
\hline SENADOR JOSÉ PORFÍRIO & $3.806 .494,98$ & $4.478 .868,67$ & $4.630 .884,59$ & $12.916 .248,24$ & $11.076 .558,40$ \\
\hline
\end{tabular}

Fonte: Sefa/PA 2018; Semas/PA, 2018.

Nota: dados trabalhados pelos autores. 
Gráfico 2. Variação entre valor repassado desde a introdução do critério ecológico (2014-2016), e o montante que seria repassado, caso não houvesse a introdução do critério ecológico, considerando o valor total da cota parte de cada município.

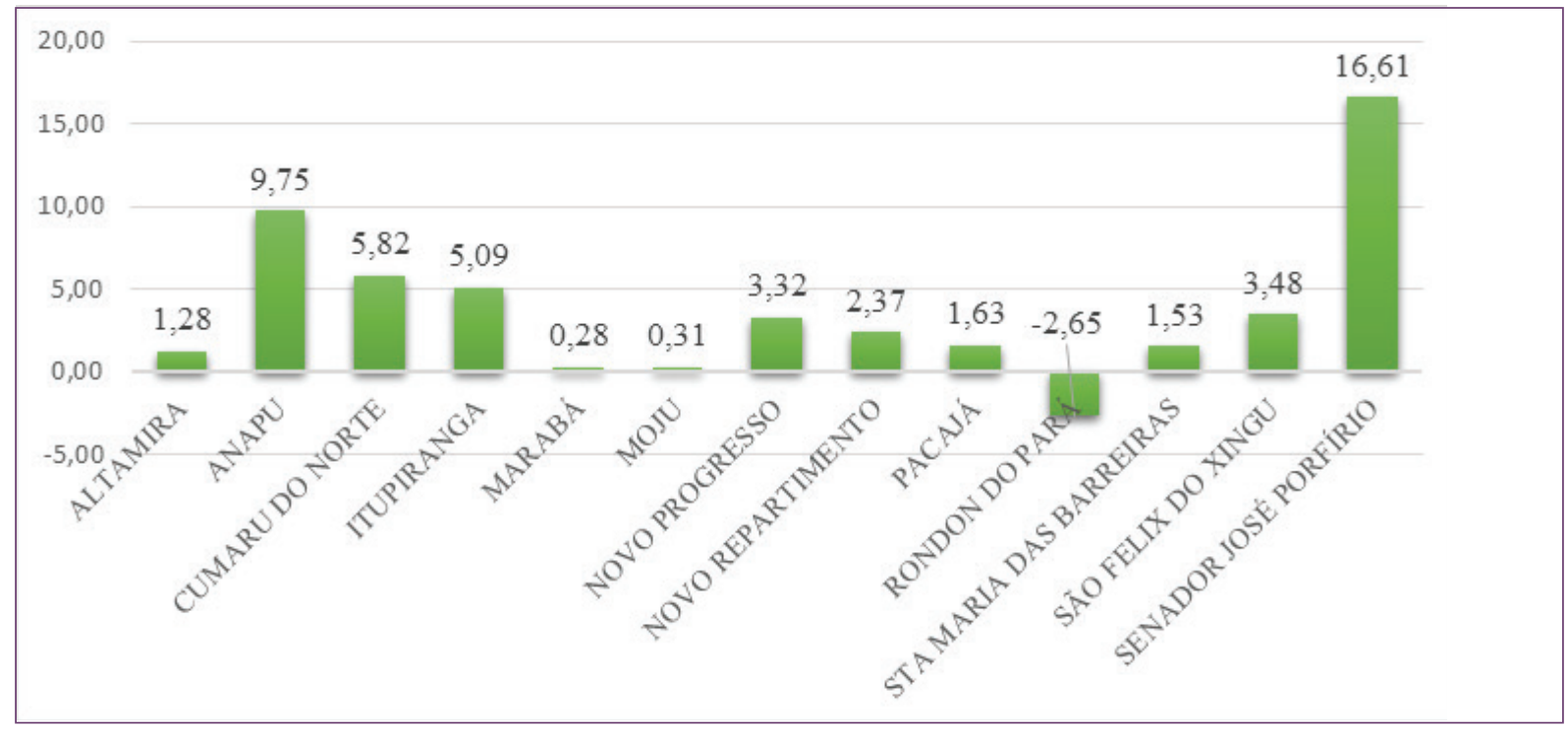

Fonte: Sefa/PA, 2018; Semas/PA, 2018.

Nota: dados trabalhados pelos autores.

Assim como no gráfico anterior, percebe-se que, em geral, os municípios prioritários paraenses perceberam aumentos de repasses financeiros com a introdução do critério ecológico, à exceção de Rondon do Pará. Apesar de São Felix do Xingu ter, segundo o primeiro gráfico, obtido o maior aumento de receita, em valores absolutos, em cotejo com o montante total recebido no período, tal ganho se mostra menos expressivo. Por sua vez, o município de Senador José Porfírio experimentou aumento bastante significativo, de mais de $16 \%$ em relação ao valor da cota parte do ICMS que the caberia, caso não houvesse ocorrido a implementação do ICMS Verde, demostrando a maior importância que o critério ecológico assume em municípios de menor população.

Dessa forma, conclui-se que, no período analisado (2014-2016), os municípios prioritários, em sua maioria, lograram aumentos de receitas transferidas, em razão da implementação do ICMS Verde. Ressalte-se, contudo, que, a partir de 2017, a repartição de receitas passou a observar os parâmetros constantes da Por- taria Semas/PA n. 1.272/2016 e Decreto n.1.696/2017, resultando em alterações significativas. ${ }^{21}$ Surge, portanto, a necessidade de analisar qual o impacto que essa reconfiguração surtirá nos repasses financeiros a esse grupo de municípios.

21 Por exemplo, a Gestão Ambiental Municipal deixa de ser condição formal para a transferência de receitas e passa a compor o próprio critério ecológico como um dos fatores de dimensionamento dos repasses. 
Desse modo, obteve-se os seguintes dados quanto ao ano de 2017:

Tabela 4. Valores de repasse para os municípios prioritários no ano de 2017, sob os critérios igualitário e ecológico, e os valores que lhes seriam repassados, sem a introdução do critério ecológico.

\begin{tabular}{|l|l|l|l|l|}
\hline MUNICÍPIOS & $\begin{array}{l}2017 \text { - Critérios ecoló- } \\
\text { gico (8\%) e Igualitário } \\
(7 \%)\end{array}$ & Igualitário (15\%) & 2017 - TOTAL & $\begin{array}{l}2017 \text { - TOTAL (sem o } \\
\text { critério ecológico) }\end{array}$ \\
\hline ALTAMIRA & $4.234 .358,52$ & $2.136 .576,63$ & $43.893 .830,35$ & $41.796 .048,46$ \\
\hline ANAPU & $2.222 .739,14$ & $2.136 .576,63$ & $6.358 .452,06$ & $6.272 .289,55$ \\
\hline CUMARU DO NORTE & $2.894 .250,97$ & $2.136 .576,63$ & $8.614 .676,99$ & $7.857 .002,65$ \\
\hline ITUPIRANGA & $2.483 .751,54$ & $2.136 .576,63$ & $8.614 .676,99$ & $8.267 .502,08$ \\
\hline MARABÁ & $2.727 .512,51$ & $2.136 .576,63$ & $123.887 .259,50$ & $123.296 .323,62$ \\
\hline MOJU & $2.222 .738,23$ & $2.136 .576,63$ & $12.306 .681,40$ & $12.220 .519,80$ \\
\hline NOVO PROGRESSO & $2.998 .196,09$ & $2.136 .576,63$ & $12.511 .792,77$ & $11.650 .173,31$ \\
\hline NOVO REPARTIMENTO & $2.656 .970,72$ & $2.136 .576,63$ & $13.332 .238,19$ & $12.811 .844,10$ \\
\hline PACAJÁ & $2.617 .613,53$ & $2.136 .576,63$ & $10.460 .679,20$ & $9.979 .642,30$ \\
\hline RONDON DO PARÁ & $2.222 .736,42$ & $2.136 .576,63$ & $9.024 .899,70$ & $8.938 .739,91$ \\
\hline STA MARIA DAS BARREIRAS & $2.600 .700,48$ & $2.136 .576,63$ & $7.589 .120,20$ & $7.124 .996,35$ \\
\hline SÃO FELIX DO XINGU & $3.846 .243,32$ & $2.136 .576,63$ & $27.074 .699,10$ & $25.365 .032,41$ \\
\hline SENADOR JOSÉ PORFÍRIO & $2.479 .595,32$ & $2.136 .576,63$ & $4.307 .338,49$ & $3.964 .319,80$ \\
\hline
\end{tabular}

Fonte: Sefa/PA, 2018; Semas/PA, 2018.

Nota: dados trabalhados pelos autores.

Gráfico 3. Variação entre os valores que seriam repassados aos municípios prioritários sob o critério igualitário em 2017, caso não houvesse a introdução do critério ecológico, e os valores estimados de repasse sob os critérios ecológico e igualitário, no mesmo ano.

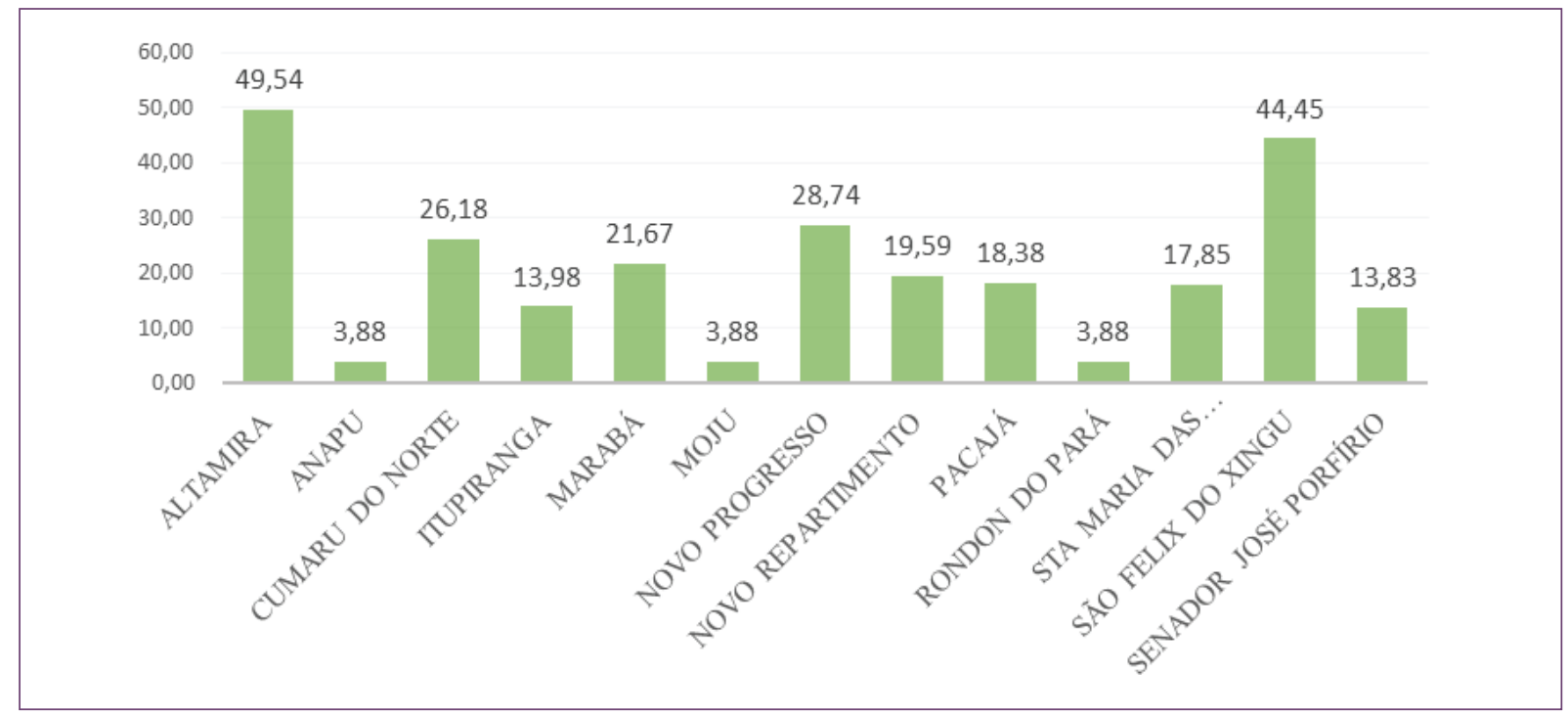

Fonte: Sefa/PA, 2018; Semas/PA, 2018.

Nota: dados trabalhados pelos autores.

Percebe-se que as alterações implementadas no ano de 2017 não alteraram o tratamento dispensado aos mu- 
Gráfico 4. Variação entre valor estimado de repasse para 2017, e o montante que seria repassado, caso não houvesse a introdução do critério ecológico, considerando o valor total da cota parte de cada município.

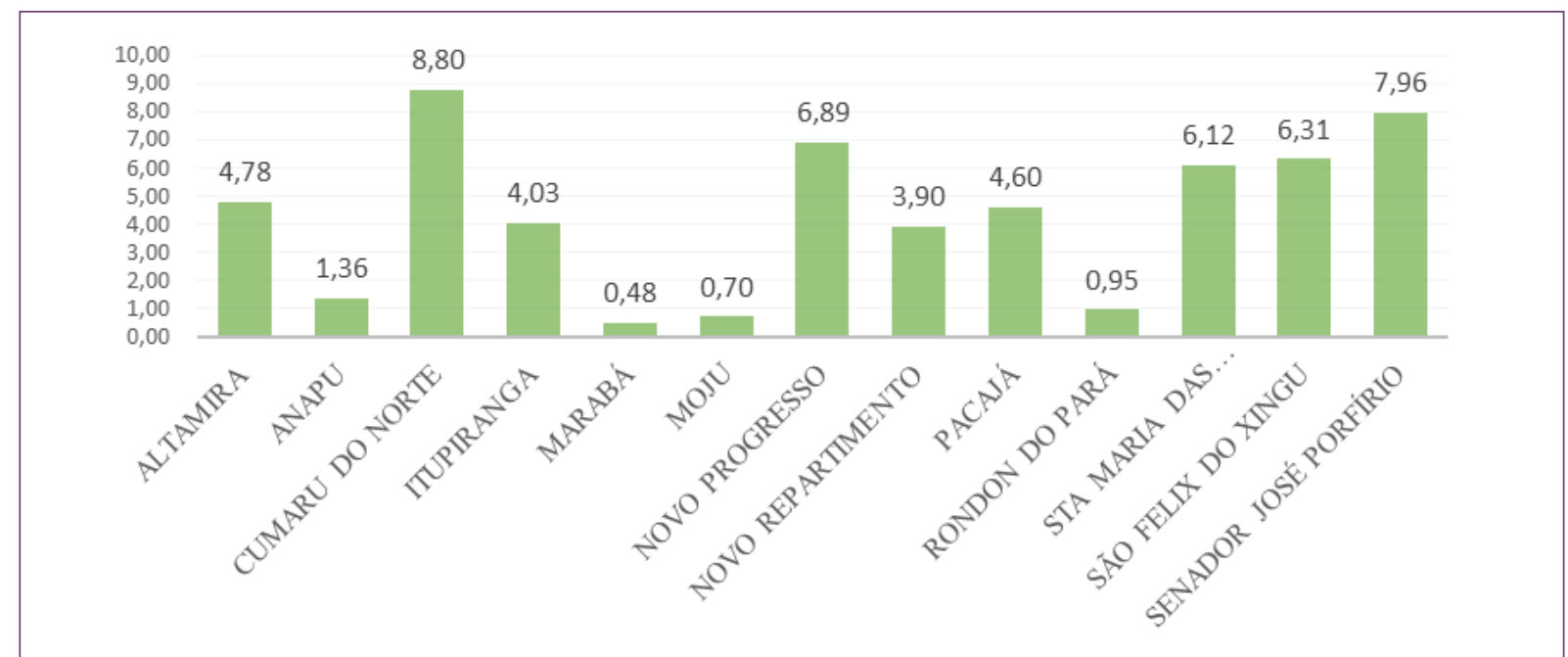

Fonte: Semas/PA, 2018.

Nota: dados trabalhados pelos autores.

nicípios prioritários nos primeiros anos de implementação do ICMS Verde. Todos os integrantes desse grupo perceberam repasses financeiros em patamar superior ao que receberiam sem a introdução do critério ecológico - incluído o município de Rondon do Pará, que saiu prejudicado, como visto, no período 2014-2016.

Além disso, a diferença em relação à forma de distribuição anterior à Lei Estadual n 7.638/2012 será também mais expressiva, destacando-se os municípios de Altamira e São Felix do Xingu, que serão os maiores recebedores de recursos sob o critério ecológico em 2017, dentre todos os municípios paraenses, conforme índices divulgados pela Semas/PA (Pará, 2017). Ressalte-se que esses municípios apresentam as maiores taxas de incremento de desmatamento no estado, desde o ano de 2012 (Instituto Nacional de Pesquisas Espaciais [INPE], 2016).

Em que pese a vantagem financeira recebida pelos municípios prioritários com a introdução da política do ICMS Verde no Estado do Pará, é interessante observar que os indicadores de desmatamento em tais entes se mantiveram persistentemente altos desde a introdução política.

Conforme o gráfico abaixo, a participação do incremento de desmatamento nesses municípios em relação ao verificado em todo o estado manteve-se relativamente estável no período. 
Gráfico 5. Evolução das taxas de incremento de desmatamento no Estado e nos municípios prioritários, em $\mathrm{km}^{2}$ (2012-2017).

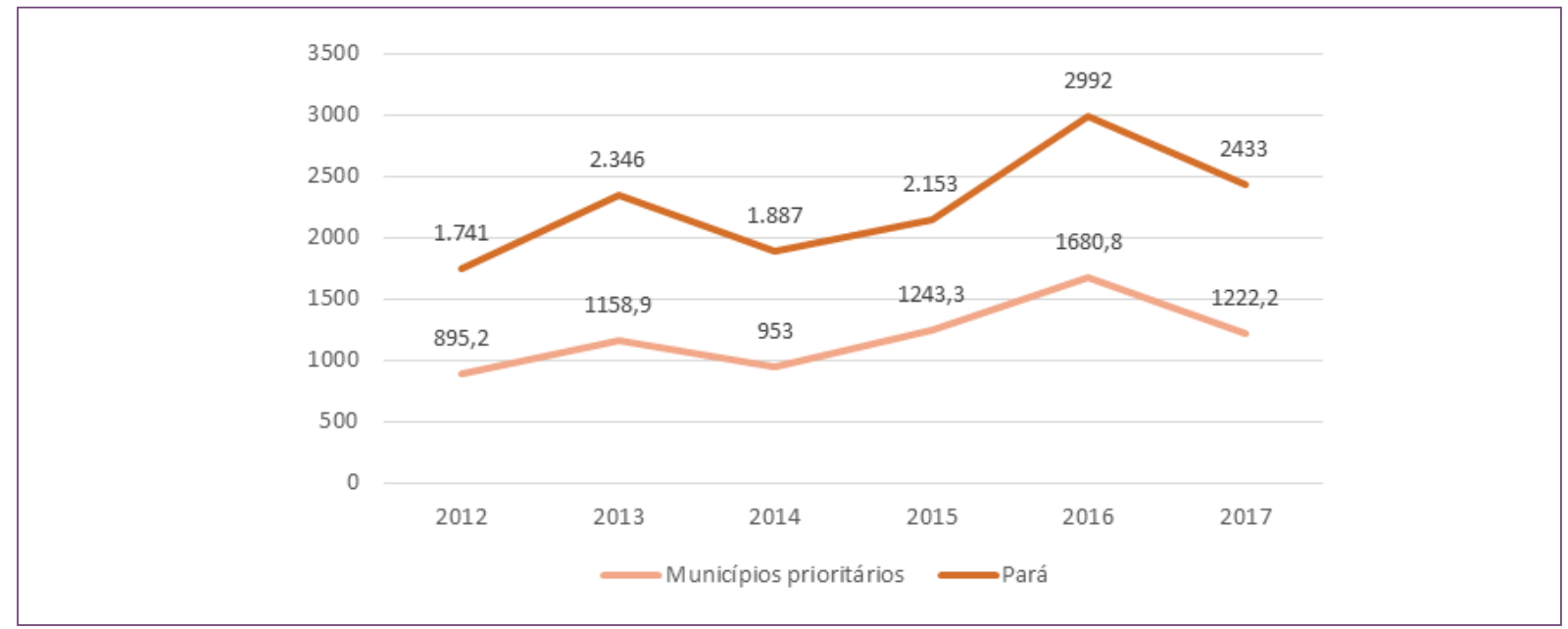

Fonte: Inpe, 2018.

Nota: dados trabalhados pelos autores.

Diante disso, ainda que a utilização da política do ICMS Verde no Estado do Pará seja relativamente recente, a manutenção de repasses consideráveis aos Municípios Prioritários e as elevadas taxas de desmatamento parecem indicar que a política, até o momento, não vem constituindo incentivo capaz de incrementar a participação dos entes municipais no combate ao desmatamento.

\section{Conclusão}

A partir da análise realizada ao longo do presente trabalho, observa-se que os impactos financeiros nos municípios prioritários decorrentes da implementação do ICMS Verde paraense não se harmonizam, até o presente momento, com os fundamentos teóricos da política, que foi implementada, no Pará, com o expresso intuito de contribuir para a redução das taxas de desmatamento.

Pelos dados apresentados, notou-se que os municípios que apresentaram as maiores taxas de desmatamento saíram beneficiados com a nova sistemática de repartição de receitas estabelecida pela Lei Estadual $n^{\circ} 7.638 / 2012$, resultado prático que contraria as diretrizes básicas de compensação e incentivo da política, bem como seu objetivo central de redução do desmatamento no estado, mediante o fomento à participação municipal.
A contradição entre os resultados verificados e os fundamentos da política pode ser explicada, ao menos em parte, pela incapacidade dos indicadores que compõem o critério ecológico paraense em expor o uso inadequado da floresta amazônica - particularmente, em espaços territoriais especialmente protegidos e assentamentos de reforma agrária, muitos dos quais situados em municípios com altas taxas de desmatamento (Ferreira, 2016). Como os indicadores utilizados apresentam natureza predominantemente quantitativa, não são capazes de mensurar conflitos de uso da floresta existentes nesses espaços.

De fato, áreas que, quantitativamente, são computadas enquanto unidades de conservação passíveis de gerar efeitos positivos para a preservação ambiental, sofrem, na realidade, acirrado processo de degradação (Tupiassu \& Oliveira, 2016), o qual permanece invisível aos indicadores utilizados pelo ICMS Verde.

Tal situação não foi alterada pelas modificações na sistemática de cálculo do repasse introduzidas em 2016, em que pese a justificativa de introdução de critérios qualitativos, visto que os municípios prioritários continuam a receber tratamento mais benéfico e, inclusive, passaram a auferir repasses financeiros ainda maiores.

No intuito de melhorar a análise qualitativa da realidade da degradação ambiental nos municípios para 
fins de repasse do ICMS Verde, pesquisas indicam que seria preferível a adoção de modelos de indicadores multidimensionais e adequados ao ecossistema amazônico. A utilização do modelo Pressão-Estado-Resposta (PER), da Organização para Cooperação e Desenvolvimento Econômico (OCDE), e dos indicadores selecionados pelo Processo de Tarapoto (Ferreira, 2016; Nóbrega, 2018), por exemplo, seriam estratégias interessantes para possibilitar que a política sirva de incentivo à adoção de condutas de preservação ambiental por parte dos entes municipais.

Em que pese o ICMS Verde ser apenas um dos instrumentos utilizados pelos entes públicos no combate ao desmatamento, o quadro de contínua degradação do ecossistema amazônico exige que se realize uma constante reavaliação estratégica, de modo a aproximá-la dos objetivos estabelecidos em sua concepção, bem como conformá-la a partir de seus fundamentos teóricos. Além disso, a introdução da nova metodologia de fixação do critério ecológico paraense é outro fator que reforça essa exigência, por demandar a observação dos efeitos práticos da alteração. Tal como qualquer política pública, é essencial que a conferência de sua adequação e eficiência na realização de seus objetivos se dê a partir de seus resultados concretos, sem descuidar de sua base teórica.

HIIIIIIIIIIIIIIIIIIIIIIIIIIIIIIIIII

\section{Referências}

Assunção, J., \& Rocha, R. (2014). Municípios Prioritários: Reputação ou Fiscalização?. Climate Policy Institute. Recuperado em 15 outubro 2016 de https://climatepolicyinitiative.org/wp-content/uploads/2014/08/Munic\%C3\%ADpios-Priorit\%C3\%A1rios-Reputa\%C3\%A7\%C3\%A3o- o u - F i s c a l i z a \% C 3 \% A 7 \% C 3 \% A 3 o _-Sum\%C3\%A1rio-Executivo.pdf.

Conti, J. M. (2001). Federalismo Fiscal e Fundos de Participação. São Paulo: Juarez de Oliveira.

Constituição da República Federativa do Brasil de 1988. Recuperado de http://www.planalto.gov. br/ccivil_03/constituicao/constituicaocompilado. htm.

Constituição do Estado do Pará (1989). Recuperado de http://pa.gov.br/downloads/ConstituicaodoParaateaEC48.pdf.

Decreto n. 775, de 26 de junho de 2013. Regulamenta a Lei Estadual no 7.638, de 12 de julho de 2012. Recuperado de https://www.semas.pa.gov. br/2013/06/27/d-e-c-r-e-t-o-no-775-de-26-dejunho-de-2013-publicado-no-doe-no-32-426de-27062013.

Decreto n. 6.321, de 21 de dezembro de 2007. Dispõe sobre ações relativas à prevenção, monitoramento e controle de desmatamento no Bioma Amazônia, bem como altera e acresce dispositivos ao Decreto no 3.179, de 21 de setembro de 1999, que dispõe sobre a especificação das sanções aplicáveis às condutas e atividades lesivas ao meio ambiente, e dá outras providências. Recuperado de http://www.planalto.gov.br/ccivil_03/_ato20072010/2007/decreto/d6321.htm.

Fadel, L. P. S. L. (2017). ICMS Verde paraense e municípios prioritários: análise da conformação da política a seus fundamentos teóricos e objetivo de redução do desmatamento. Relatório Científico do Programa Institucional de Bolsas de Iniciação Científica. Belém: UFPA.

Ferreira, L. C. D. S. (2016). ICMS Verde: um estudo sobre a adequação de seus indicadores à sustentabilidade amazônica. 2016. 131 p. Dissertação (Mestrado em Direito, Políticas Públicas e Desenvolvimento Regional) - Programa de Pós-graduação Strictu Sensu, Centro Universitário do Estado do Pará.

Fonseca, A. et al (2015). Boletim do desmatamento da Amazônia Legal (julho de 2015) SAD. Belém: 
Imazon. Recuperado em 15 outubro 2016 de http://imazon.org.br/PDFimazon/Portugue s/ transparencia_florestal/amazonia_legal/SAD\%20 Julho\%202015.pdf.

Fonseca, A. et al (2016). Boletim do desmatamento da Amazônia Legal (julho de 2016) SAD. Belém: Imazon. Recuperado em 15 outubro 2016 de http://imazon.org.br/PDFimazon /Portugues/ transparencia_florestal/amazonia_legal/SAD\%20 julho\%202016.pdf.

Instituto Brasileiro de Geografia e Estatística [IBGE] (2010). Censo demográfico 2010. Recuperado em 15 outubro 2016 de http://cidades.ibge.gov.br/ xtras/uf.php ?lang=\&coduf=15\&search=para.

Instituto Nacional de Pesquisas Espaciais [INPE] (2016). Taxas anuais do desmatamento - 1988 até 2016. Recuperado em 15 outubro 2016 de http://www.obt. inpe.br/prodes/prodes_1988_2016n.htm.

Instituto Nacional de Pesquisas Espaciais [INPE] (2018). PRODES municipal. Recuperado em 11 junho 2018 de http://www.dpi.inpe.br/prodesdigital/prodesmunicipal.php.

Lei Complementar $n^{\circ}$ 63, de 11 de janeiro de 1990. Dispõe sobre critérios e prazos de crédito das parcelas do produto da arrecadação de impostos de competência dos Estados e de transferências por estes recebidos, pertencentes aos Municípios, e dá outras providências. Recuperado de http://www.planalto. gov.br/ccivil_03/leis/LCP/Lcp63.htm.

Lei Estadual n. 7.638, de julho de 2012. Dispõe sobre o tratamento especial de que trata o $\S 2^{\circ}$ do art. 225 da Constituição do Estado do Pará. Recuperado em 15 outubro 2016 de https://www.semas.pa.gov. br/wp-content/uploads/2015/11legislacao/estadual/Lei_Estadual_no_7.638_ICMS_VERDE.pdf.

Lei Estadual n. 8.458 de 28 de dezembro de 2016. Estima a receita e fixa a despesa do Estado do Pará para o exercício financeiro de 2017 e dá outras providências. Recuperado em 06 fevereiro de 2017 de http://seplan.pa.gov.br/loa-2017.

Lévêque, F. (1999). Externalities, Collective Goods and the Requirement of a State's Intervention in Pollution Abatement. In: Lévêque, F. \& Carraro, C., Voluntary Approaches in Environmental Policy. Dordrecht: Springer Netherlands.

Marshall, A. (1920). Principles of Economics. London, Macmillan and Co.

Ministério do Meio Ambiente [MMA] (2016). Lista de
Municípios Prioritários da Amazônia. Recuperado em 15 outubro 2016 de http://www.mma.gov.br/ florestas/controle-e-prevenção-do-desmatamento/plano-de-ação-para-amazônia-ppcdam/lista-de-municípios-prioritários-da-amazônia.

Ministério do Meio Ambiente [MMA] (2016). Plano de Prevenção e Controle do Desmatamento na Amazônia Legal. Recuperado em 15 outubro 2016 de http://www.mma.gov.br/florestas/ controle-e-preven $\% \mathrm{C} 3 \% \mathrm{~A} 7 \% \mathrm{C} 3 \% \mathrm{~A} 30$-do-desmatamento/plano-de-a\%C3\%A7\%C3\%A3o-para-amaz\%C3\%B4nia-ppcdam.

Neves, E. M. S.C. (2015). O processo de municipalização da estratégia de prevenção e combate ao desmatamento na Amazônia: estudos de casos sobre municipios integrantes da Lista de Municípios Prioritários do Ministério do Meio Ambiente. Climate and Land Use Alliance - CLUA. Recuperado em 15 outubro 2016 de http://municipiosverdes.com.br/files/999 816d7a617e650c796109566e 1337c/3def184ad8f4 755ff269862ea77393dd/Estudo_\%20Processo\%20 de\%20municipaliza\%C3\%A7ao\%20combate\%20 ao\%20desmatamento\%20na\%20Amazonia.pdf.

Nóbrega, B. M. (2018) O ICMS Verde como instrumento e equidade intraestadual no Pará. Dissertação (Mestrado em Direito, Políticas Públicas e Desenvolvimento Regional) - Programa de Pós-graduação Strictu Sensu, Centro Universitário do Estado do Pará.

Oliveira, A. C. (2014). Icms ecológico e desenvolvimento: análise dos Estados de Rondônia, Tocantins, Ceará e Pará. Dissertação (Mestrado em Direito, Políticas Públicas e Desenvolvimento Regional) Programa de Pós-graduação Strictu Sensu, Centro Universitário do Estado do Pará.

Pigou, A. C. (1929). The Economics of Welfare. London: Macmillan and Co.

Porfírio, N. D. F., Jr. (2004). Federalismo, tipos de Estado e conceito de Estado Federal. In: Conti, J. M. (org.). Federalismo Fiscal. Barueri.

Portaria do Ministério do Meio Ambiente n. 411, de 7 de outubro de 2013. Dispõe sobre os requisitos de 2013 para que os municípios listados pelas Portarias $n^{\circ} 28$, de 24 de janeiro de 2008, 102, de 24 de março de 2009, 66, de 24 de março de 2010, 175, de 24 de maio 2011 e 323, de 28 de setembro de 2012 do Ministério do Meio Ambiente passem a integrar a lista de municípios com desmatamen- 
to monitorado e sob controle. Recuperado em 15 outubro 2016 de http://www.mma.gov.br/ images/noticias_arquivos/pdf/2013/outubro_13/ materia_11_10_cinco_municipios_deixam_lista_ dos_que_mais_desmatam_na_amazonia_link_ dou.pdf.

Portaria Semas/PA n. 1.272 de 21 de Julho de 2016. Publica os dados, informações e índices definitivos referentes ao repasse do ICMS Verde aos municípios e dá outras providências. Secretaria de Estado de Meio Ambiente e Sustentabilidade. Recuperado em 06 fevereiro 2017 de https://www.semas. pa.gov.br/2016/07/22/portaria-no-1272-de-21-de-julho-de-2016.

Portaria Semas/PA n 1.310 de 03 de agosto de 2017. Publica os dados, informações e índices definitivos referentes ao repasse do ICMS Verde aos municípios e dá outras providências. 2017a. Disponível em: < https://www.semas.pa.gov. br/2017/08/07/portaria-n1310-de-0382017-publicada-no-doe-n33432-de-7817-pag-38-e-39/>. Acesso em 15 jun. 2017.

Scaff, F. F., \& Tupiassu, L. V. C. (2005). Tributação e Políticas Públicas: O ICMS Ecológico. In: TORRES, H. T. (Org.), Direito Tributário Ambiental. São Paulo: Malheiros, p. 724-748.

Secretaria de Estado da Fazenda (Sefa/PA). Repasse de ICMS aos Municípios. Recuperado em 01 junho 2018 de http://www.sefa.pa.gov.br/index.php/receitas-despesas/tesouro/icms/534-repasse-icms.

Secretaria de Estado de Meio Ambiente e Sustentabilidade (2016). Diretrizes metodológicas e detalhamento dos critérios de repasse do ICMS Verde no Estado do Pará: porção municipal. Recuperado em 20 novembro 2016 de https://www.semas.pa.gov. br/wp-ontent/uploads/2016/05/ NOVA_METODOLOGIA_1.pdf.

Secretaria de Estado de Meio Ambiente e Sustentabilidade (2018). Valores de repasse. Recuperado em 20 novembro 2016 de https://www.semas.pa.gov. $\mathrm{br} /$ icms-verde/valores-de-repasse/.

Silva, J. A. (2015). Curso de Direito Constitucional Positivo. 38. ed. São Paulo: Malheiros.

Tupiassu, L. V. C. (2006). Tributação ambiental: a utilização de instrumentos econômicos e fiscais da implementação do direito ao meio ambiente saudável. Rio de Janeiro: Renovar.

Tupiassu, L. V. C. (2010). Desenvolvimento econômico sustentável e tributação ambiental: breves fundamentos e perspectivas de estudo. In: Dias, J. C. \& Filho, P. K. (Coords.), Direitos fundamentais, teoria do direito e sustentabilidade. São Paulo: Método; Belém: Cesupa, 2010, p. 107-126.

Tupiassu, L. V. C., \& Oliveira, A. C. (2016). ICMS Verde para a redução do desmatamento amazônico: estudo sobre uma experiência recente. Veredas do Direito, Belo Horizonte, v. 13, n. 25, p. 277-306.

Tupiassu, L. V. C. \& Haber, L. M. (2014). Quota-parte do ICMS e Desenvolvimento Sustentável: A nova Lei do ICMS Ecológico no Estado do Pará. In: Dias, J. C.; Gomes, M. A. M., Direito e Desenvolvimento. São Paulo: Método, p. 295-312.

Whately, M. (2013). Programa Municípios Verdes: lições aprendidas e desafios para 2013/2014. Belém/PA. Governo do Estado. Programa Municípios Verdes. Recuperado em 15 outubro 2017 de http://www. municipiosverdes.pa.gov.br/files/999816d7a617 e650c796109566e1 337c/d67d8ab4f4c10bf22aa353e27879133c/PMV_Li\%C3\%A7\%C3\%B5es\%20 Aprendidas $\% 20$ e $\% 20$ desafios $\% 20$ para $\% 20$ 2013_2014.pdf.

Data de submissão/Submission date: 27.04.2017. Data de aceitação para publicação/Acceptance date: 19.06.2018. 